\title{
Modtagne bøger
}

N.F. S. Grundtvig: Blik paa Poesiens Historie og Bernhard Severin Ingemann. Manuskript fra $1822 \mathrm{udg}$. med indledning og noter af Flemming Lundgreen-Nielsen. Museum Tusculanums Forlag København 1985.

N.F. S. Grundtvig. Theolog og kirkelarer. Prædikener og foredrag af R. Prenter, J. Glenthøj, Hejne Simonsen, S. Poulsen og Arthur Mac Donald. Udg. af Konvent for Kirke og Theologi. 1983.

Regin Prenter: Den kirkelige anskuelse. Udg. af Konvent for Kirke og Theologi. 1983.

Poul Dam: Politikeren Grundtvig. Udg. af Folketingets Præsidium og forlaget Aros. 1983.

Grundtvig og grundtvigianismen i nyt lys. Hovedtanker og Udviklingslinier Fra de senere Års Grundtvigforskning. Redaktion: Christian Thodberg og Anders Pontoppidan Thyssen. Forlaget ANIS i samarbejde med Det danske Selskab. Århus 1983. (Dansk udgave af den på engelsk, tysk og fransk udsendte Grundtvigbog, der tillige behandler grundtvigianismen indtil omkring 1900.)

Danske salmer $i$ tysk oversattelse. Oversættelser af Andreas Øster. Skandia Verlag Flensburg 1983.

Kirchenlieder von N. F. S. Grundtvig. Redaktion Jørgen Kristensen. Udg. af Det danske Selskab 1983.

Kalejdoskop våren 1984, udg. af Lærerrådet ved Københavns Dagog Aftenseminarium (Ejbyvej 25-43, 2740 Skovlunde, $15 \mathrm{kr}$.)

Niels Kofoed: Grundtvig som mytolog og historiker

Erik Sveidahl: Grundtvigs pædagogiske tanker

Sven Borgen: Grundtvig og u-landene

Paul Heide: Grundtvigs salmer og sange i skolen

Helmer Norgaard: Melodier til Grundtvigs salmer og sange (En række folkelige foredrag om Grundtvig, holdt ved seminariet, med offentlig adgang, Rigt illustreret. - Til det sidste foredrag er føjet en liste over folkelige sangbøger 1778-1943 og over vigtige komponister til den folkelige danske sang, og nogle betragtninger "om at sætte musik til Grundtvig". Bogen indeholder tillige et nodebilag med musik til følgende digte af Grundtvig, kompone- 
ret af Helmer Nørgaard: Skovhuset i Sælland, Jule-Træet, og De Levendes Land, samt salmen Lille Guds barn, hvad skader dig.) Århushistorier, lokalspil i en storby, udg. af Institut for Dramaturgi, i serien Aktuelle teaterproblemer, Ârhus 1983. (Heri forekommer et gadespil om Grundtvig, opført uden for Aarhus Katedralskole og i Katedralskolens gård. "Vi valgte at gøre det lidt uhøjtideligt for at skabe bred interesse for hans tanker hos et publikum på gaden ", skriver John Andreasen, der har redigeret bogen.)

Erik M. Christensen: Henrik Ibsens realisme. Bind 1-2. Akademisk Forlag København 1985. 